\title{
CORRIGENDUM
}

\section{Susceptibility to lethal cerebral malaria is regulated by epistatic interaction between chromosome 4 (Berr6) and chromosome 1 (Berr7) loci in mice}

S Torre, R van Bruggen, JM Kennedy, J Berghout, SE Bongfen, P Langat, M Lathrop, SM Vidal and P Gros

Genes and Immunity (2013) 14, 470; doi:10.1038/gene.2013.50

Correction to: Genes and Immunity (2013) 14, 249-257;

doi:10.1038/gene.2013.16; published online 18 April 2013

Since the publication of this paper, the authors wish to correct the nomenclature of the Berr6 locus described in the above paper. The Berr6 designation has been changed to Berr8.

The authors apologize for any inconvenience caused. 